\title{
PROFIL GURU HARAPAN MASA DEPAN
}

\section{THE PROFILE OF TEACHER AS A FUTURE HOPE}

\author{
A. Marjuni'), Alwan Suban'2) \\ 1,2)Universitas Islam Negeri Alauddin Makassar \\ h.marjunij@yahoo.com¹), alwan.suban@uin-alauddin.ac.id²)
}

\begin{abstract}
Abstrak
Guru adalah pendidik profesional dengan tugas untuk mendidik, mengajar, membimbing, mengarahkan, melatih, menilai, dan mengevaluasi peserta didik pada pendidikan anak usia dini jalur pendidikan formal, pendidikan dasar, dan pendidikan menengah. Guru mempunyai kedudukan sebagai tenaga profesional pada jenjang pendidikan dasar, pendidikan menengah, dan pendidikan anak usia dini pada jalur pendidikan formal yang diangkat sesuai dengan peraturan perundang-undangan yaitu: pertama, pengakuan kedudukan guru sebagai tenaga profesional dibuktikan dengan sertifikat pendidik. Kedua, kedudukan guru sebagai tenaga profesional berfungsi untuk meningkatkan martabat dan peran guru sebagai agen pembelajaran berfungsi untuk meningkatkan mutu pendidikan nasional. Ketiga, kedudukan guru dan dosen sebagai tenaga profesional bertujuan untuk melaksanakan sistem pendidikan nasional dan mewujudkan tujuan pendidikan nasional, yaitu berkembangnya potensi peserta didik agar menjadi manusia yang beriman dan bertakwa kepada Tuhan Yang Maha Esa, berakhlak mulia, sehat, berilmu, cakap, kreatif, mandiri, serta menjadi warga negara yang demokratis dan bertanggung jawab.
\end{abstract}

Kata Kunci: profil, guru, harapan

\begin{abstract}
A teacher is a professional educator with the task of educating, teaching, guiding, directing, training, assessing, and evaluating students in early childhood education through formal education, basic education, and secondary education. The teacher has a position as a professional at the level of basic education, secondary education, and early childhood education in the formal education pathways that are appointed by laws and regulations, namely: first, the recognition of the position of teachers as professionals as evidenced by certificates of educators. Second, the position of the teacher as a professional staff function to improve the dignity and the role of the teacher as a learning agent functions to improve the quality of national education. Third, the position of the teacher and lecturer as professional staff aims to implement the national education system and realize the national education goals, namely the development of the potential of students so that be a human being who believes and is devoted to Allah Almighty, noble, healthy, knowledgeable, competent, creative, capable, and becomes a democratic and responsible citizen.
\end{abstract}

Keywords: profile, teacher, hope

How to Cite: Marjuni, A. \& Suban, A. (2020). Profil guru harapan masa depan. Al asma: Journal of Islamic Education, 2(1), 13-22. 


\section{PENDAHULUAN}

Undang-undang Nomor 20 Tahun 2003 tentang SISDIKNAS turunan pasal 1 butir 6: "Pendidik adalah tenaga kependidikan yang berkualifikasi guru, dosen, pamong belajar, widyaiswara, tutor, instruktur, fasilitator, dan sebutan lainnya yang sesuai dengan kekhususannya, serta berpartisipasi dalam menyelenggarakan pendidikan. Masalah guru adalah masalah yang penting. Masalah mutu guru sangat tergantung kepada sistem pendidikan pada umumnya, sehingga mutu pendidikan guru harus ditinjau dari dua kriteria pokok, yakni kriteria produk dan kriteria proses.

Sistem pendidikan guru sebagai suatu sub sistem pendidikan nasional merupakan faktor kunci dan memiliki peran yang sangat strategis. Pada hakikatnya penyelenggaraan dan keberhasilan proses pendidikan pada semua jenjang pendidikan ditentukan oleh faktor guru, di samping perlunya unsur-unsur penunjang lainnya. Kualitas kemampuan guru yang rendah akan berdampak pada rendahnya mutu pendidikan, sedangkan derajat guru sejak dulu disiapkan pada suatu lembaga pendidikan baik secara berjenjang maupun secara keseluruhan. Kebutuhan bangsa Indonesia akan pendidikan sangat dirasakan sejak penjajahan Belanda dalam memperkenalkan politik etisnya kepada bangsa Indonesia dengan mendirikan berbagai macam pendidikan untuk mempersiapkan tenaga yang siap pakai pada masa itu. Pendidikan yang terjadi di masa penjajahan telah membawa dampak bagi kemajuan anak bangsa di masa itu. Meskipun dalam sejarah manusia pernah mengalami masa kegelapan, pencerahan awal modern, dan sekarang saatnya manusia sudah harus siap tampil di masa postmodern. Masing-masing zaman tentu memiliki karakter dan kebutuhan sendiri. Pendidikan merupakan mata rantai yang dapat menghubungkan dunia masa lalu, dunia masa sekarang, dan masa yang akan datang. Setiap nilai sejarah yang ada di masa lalu dapat diketahui dan kemudian diwariskan kepada generasi muda di masa sekarang. Dengan demikian, apapun persoalan kehidupan di masa yang akan datang senantiasa dapat dipersiapkan sedini mungkin dengan melakukan pemberdayaan potensi manusia yang bercermin kepada nilai sejarah masa lalu. Saat ini profesi guru memang dirasakan sedang naik daun dan tidak sedikit orang untuk memilih profesi untuk menjadi guru. Di samping rekrutmen untuk menjadi guru yang digunakan tidak begitu ketat, dan juga adanya berbagai tunjangan yang akan didapatkan bagi seorang guru dalam menjalankan profesinya.

Rekrutmen guru secara profesional merupakan hal yang wajib dilakukan. Hal ini dimaksudkan untuk mendapatkan calon guru yang sangat potensial dalam menjalankan profesinya berdasarkan kemampuan yang dimilikinya. Namun tidak mudah untuk mendapatkan calon guru yang betul-betul sesuai. Dalam rangka mendapatkan calon guru yang profesional, memiliki kualifikasi, dan sanggup untuk menjalankan profesinya itu dengan sikap serius tidaklah mudah. Ada beberapa prinsip yang harus dipegang teguh dalam perencanaan maupun pelaksanaan rekrutmen guru, diantaranya:

1. Rekrutmen guru harus dirancang secara matang agar dapat memenuhi kebutuhan.

2. Rekrutmen guru harus dilakukan secara objektif. Artinya, secara objektif panitia atau lembaga penjamin mutu pendidikan melakukan rekrutmen guru dengan menetapkan pelamar yang lulus, dan sebaliknya pelamar yang tidak memenuhi persyaratan tidak lulus. 
3. Agar didapatkan calon yang profesional, materi seleksi calon guru harus komprehensif mencakup semua aspek persyaratan yang harus dimiliki oleh calon guru. (Bafadal, I, 2008)

Salah satu prinsip dalam rekrutmen guru sebagaimana ditegaskan di atas adalah rekrutmen guru harus dirancang sedemikian rupa sehingga mendapatkan calon guru yang sesuai dengan kebutuhan pendidikan. Dengan adanya prinsip tersebut, sebelum dilakukan rekrutmen, sebaiknya terlebih dahulu dilakukan analisis kebutuhan dalam rangka mendapatkan formasi kebutuhan yang sesuai dengan keinginan pendidikan.

Mekanisme rekrutmen guru yang baik harus mampu mengukur tentang tingkat motivasi, komitmen, dan kepribadian pelamar. Setiap calon guru yang menjadi pelamar harus memiliki kecintaan terhadap anak, mempunyai dedikasi yang tinggi dalam menunaikan tugasnya, muda dan gesit dalam bertindak, menunjukkan kehangatan dalam berkomunikasi, memiliki kesabaran yang memadai dalam memberikan layanan pendidikan, dan memiliki selera humor untuk merubah wajah pendidikan yang sedang "murung" (Drajat, M., 2014).

\section{PEMBAHASAN}

\section{Profil Guru Masa Depan}

Pendidikan merupakan suatu rekayasa untuk mengendalikan learning guna mencapai tujuan yang direncanakan secara efektif dan efisien. Dalam proses rekayasa ini, peranan "teaching" amat penting, karena merupakan kegiatan yang dilakukan oleh guru untuk mentransfer pengetahuan, keterampilan, dan nilai kepada siswa sehingga apa yang ditransfer memiliki makna bagi diri sendiri, dan berguna tidak saja bagi dirinya tetapi juga bagi masyarakat.

Mengajar hanya dapat dilakukan dengan baik dan benar oleh seseorang yang telah melewati pendidikan tertentu yang memang dirancang untuk mempersiapkan guru. Dengan kata lain, mengajar merupakan suatu profesi. Sejalan dengan perkembangan ilmu pengetahuan dan masyarakat, muncul dua kecenderungan. Pertama, proses mengajar menjadi sesuatu kegiatan yang semakin bervariasi, kompleks, dan rumit. Kedua, ada kecenderungan pemegang otoritas struktural, ingin memaksakan kepada guru untuk mempergunakan suatu cara mengajar yang kompleks dan sulit. Sebagai akibat munculnya dua kecenderungan di atas, maka guru dituntut untuk menguasai berbagai metode mengajar dan diharuskan menggunakan metode tersebut. Misalnya, mengharuskan mengajar dengan Cara Belajar Siswa Aktif (CBSA). Untuk itu, guru harus dilatih dengan berbagai metode dan perilaku mengajar yang dianggap canggih. Demikian pula di lembaga pendidikan guru, para mahasiswa diharuskan menempuh berbagai mata kuliah yang berkaitan dengan mengajar. Namun sejauh ini, perkembangan mengajar yang semakin kompleks dan rumit belum memberikan dampak terhadap mutu siswa secara signifikan. Tidaklah mengherankan jika kemudian muncul pertanyaan mengapa mengajar menjadi sedemikian kompleks dan rumit?

a. Profesi mengajar

Pekerjaan profesional dapat dikelompokkan ke dalam dua kategori, yaitu hard profession dan soft profession. Suatu pekerjaan dapat dikategorikan sebagai hard profession apabila pekerjaan tersebut dapat didetailkan dalam perilaku dan langkahlangkah yang jelas dan relatif pasti. Pendidikan yang diperlukan bagi profesi ini adalah 
menghasilkan output pendidikan yang dapat distandarisasikan. Artinya, kualifikasi lulusan jelas dan seragam dimanapun pendidikan itu berlangsung. Dengan kualifikasi ini seseorang sudah mampu dan akan terus mampu melaksanakan tugas profesinya secara mandiri meskipun tanpa pendidikan lagi. Pekerjaan dokter dan pilot merupakan contoh yang tepat untuk mewakili kategori hard profession. Sebaliknya, kategori soft profession adalah diperlukannya kadar seni dalam melaksanakan pekerjaan tersebut.

Mengajar merupakan suatu seni untuk mentransfer pengetahuan, keterampilan dan nilai-nilai yang diarahkan oleh nilai-nilai pendidikan, kebutuhankebutuhan individu siswa, kondisi lingkungan, dan keyakinan yang dimiliki oleh guru. Dalam proses belajar mengajar, guru adalah orang yang akan mengembangkan suasana bebas bagi siswa untuk mengkaji apa yang menarik, mengekspresikan ide-ide dan kreatifitasnya dalam batas norma-norma yang ditegakkan secara konsisten. Guru juga akan berperan sebagai model bagi para siswa. Kebesaran jiwa, wawasan dan pengetahuan guru atas perkembangan masyarakat akan mengantarkan para siswa untuk dapat berpikir melewati batas kekinian, berpikir untuk menciptakan masa depan yang lebih baik.

b. Dimensi mengajar

Proses transfer pengetahuan atau sering dikenal sebagai istilah proses belajar mengajar (PBM). PBM memiliki dua dimensi. Pertama adalah aspek kegiatan siswa, apakah kegiatan yang dilakukan siswa bersifat individual atau bersifat kelompok. Kedua, aspek orientasi guru atas kegiatan siswa, apakah difokuskan pada individu atau kelompok. Berdasarkan dua dimensi yang masing-masing memiliki dua kutub tersebut terdapat empat model pelaksanaan PBM. Pertama, self-study, yakni kegiatan siswa dilaksanakan secara individual dan orientasi guru dalam mengajar juga bersifat individu. Model pertama ini memusatkan perhatian diri siswa. Agar siswa dapat memusatkan perhatian perlu diarahkan oleh dirinya sendiri dan bantuan dari luar, yakni guru. Siswa harus dapat mengintegrasikan pengetahuan baru yang diterima ke dalam pengetahuan yang telah dimiliki. Untuk pelaksanaan model self-study perlu didukung dengan peralatan teknologi, seperti komputer. Keberhasilan model ini ditentukan terutama oleh kesadaran dan tanggung jawab pada diri sendiri.

Kedua, cara mengajar tradisional. Model ini memiliki aktifitas siswa bersifat individual dan orientasi guru mengara pada kelompok. Pada model ini kegiatan utama siswa adalah mendengar dan mencatat apa yang diceramahkan guru. Ketiga, model persaingan. Model ini memiliki aktivitas yang bersifat kelompok, tetapi orientasi guru bersifat individu. Model ini menekankan partisipasi siswa dalam kegiatan PBM, semua siswa harus aktif dalam kegiatan kelompok tersebut. Seberapa jauh siswa dapat berpartisipasi dalam kegiatan akan ditentukan oleh seberapa jauh kegiatan memiliki kebebasan dan dapat dihayati merupakan hasil diskusi dengan temannya. Kempat, model cooperative-collaborative. Model ini memiliki aktivitas siswa yang bersifat kelompok. Model ini menekankan kerja sama di antara para siswa. Kegiatan siswa diarahkan untuk mencapai tujuan bersama yang telah merupakan konsensus di antara mereka. Konsensus ini didasarkan pada nilai-nilai yang dihayati bersama. Oleh karena itu, dalam kelompok senantiasa dikembangkan pengambilan keputusan. Kebersamaan 
dan kerjasama dalam pembelajaran merupakan kerja sama di antara para siswa untuk mencapai belajar bersama.

Keempat model tersebut tidak ada yang lebih baik satu atas yang lain. Sebab model mengajar yang baik adalah model belajar yang cocok dengan karakteristik materi, kondisi siswa, kondisi lingkungan, dan kondisi fasilitas. Di samping itu, keempat model tersebut saling melengkapi dalam proses pembelajaran dalam mencapai tujuan yang diinginkan.

c. Kemampuan yang dibutuhkan guru

Agar dapat melaksanakan empat langkah tersebut di atas, guru memerlukan tiga kemampuan dasar, yaitu a) didaktik, yaitu kemampuan untuk menyampaikan sesuatu secara oral atau ceramah yang dibantu dengan buku teks, demonstrasi, dan alat bantu tradisional lain; b) coaching, yaitu guru memberikan kesempatan kepada siswa untuk berlatih dan mempraktekkan keterampilannya, mengamati sejauh mana siswa mampu mempraktekkan keterampilan tersebut, serta segera memberikan umpan balik atas apa yang dilakukan siswa; dan c) socratic atau mauitic question, yaitu guru menggunakan pertanyaan pengarah untuk membantu siswa mengembangkan pandangan dan internalisasi terhadap materi yang dipelajari. Tanpa menguasai tiga kemampuan dasar tersebut, ibaratnya pemain sepak bola yang tidak memiliki kemampuan dasar bermain bola, seperti bagaimana menendang atau heading yang baik dan benar, betapa pun dididik dengan gaya samba Brazil atau gerendel Italia tetap saja tidak akan dapat memenangkan pertandingan. Demikian pula bagi guru, tanpa memiliki tiga kemampuan dasar tersebut, berapapun para guru dilatih berbagai metode mengajar yang canggih tetap saja prestasi siswa tidak dapat ditingkatkan. Sebaliknya, dengan menguasai tiga kemampuan dasar tersebut, metode mengajar apapun akan dapat dilaksanakan dengan mudah oleh yang bersangkutan.

\section{Harapan Guru Masa Depan}

Guru memegang peran yang sangat penting dalam proses pencapaian tujuan pendidikan. Untuk itu, diperlukan guru yang kreatif dan menyenangkan sehingga mampu menciptakan iklim pembelajaran yang kondusif, suasana pembelajaran yang menantang dan mampu membelajarkan dengan menyenangkan. Hal ini penting, terutama dalam setiap pembelajaran guru memiliki peranan yang sangat sentral, baik sebagai perencana, pelaksana maupun evaluator pembelajaran, terutama di sekolah dasar.

Kualitas pembelajaran sangat bergantung pada profesionalitas guru dalam memberikan kemudahan belajar kepada peserta didik secara efektif. Syaodih (1988) mengemukakan bahwa guru memegang peranan yang cukup penting baik dalam perencanaan maupun dalam pelaksanaan kurikulum. Guru juga merupakan barisan pengembang kurikulum yang terdepan, maka guru pulalah yang selalu melakukan evaluasi dan penyempurnaan terhadap kurikulum. Menyadari hal tersebut, maka sangat penting untuk meningkatkan aktivitas, kreativitas, kualitas, dan profesionalisme guru. Hal tersebut lebih nampak lagi dalam pendidikan yang dikembangkan secara desentralisasi sejalan dengan kebijakan otonomi daerah, karena guru diberi kebebasan untuk memilih dan mengembangkan materi standar dan kompetensi dasar sesuai dengan kondisi serta kebutuhan daerah dan sekolah. 
Kualitas guru dapat ditinjau dari dua segi, yaitu dari segi proses dan dari segi hasil. Dari segi proses, guru dikatakan berhasil apabila mampu melibatkan sebagian besar peserta didik secara aktif, baik fisik, mental maupun sosial dalam proses pembelajaran. Di samping itu, dapat dilihat dari segi gairah dan semangat mengajarnya, serta adanya rasa percaya diri. Dari segi hasil, guru dikatakan berhasil apabila pembelajaran yang diberikan mampu mengubah perilaku sebagian besar pendidik ke arah penguasaan kompetensi dasar yang lebih baik.

Untuk memenuhi kebutuhan tersebut, diperlukan berbagai kompetensi pembelajaran. Pengembangan kualitas guru merupakan suatu proses yang kompleks dan melibatkan berbagai faktor yang saling terkait. Oleh karena itu, dalam pelaksanaannya tidak hanya menuntut keterampilan teknis dari para ahli terhadap pengembangan kompetensi guru, tetapi harus pula dipahami berbagai faktor yang memengaruhinya. Sehubungan dengan itu, perlu dilakukan berbagai upaya untuk meningkatkan kualitas guru dalam mengembangkan berbagai aspek pendidikan dan pembelajaran.

Dalam pelaksanaan berbagai kebijakan di atas, guru dituntut untuk menjadi ahli penyebar informasi yang baik, karena tugas utamanya antara lain menyampaikan informasi kepada peserta didik. Guru juga berperan sebagai perencana (designer), pelaksana (implementer) dan penilai (evaluator) pembelajaran. Apabila pembelajaran diarahkan untuk memenuhi kebutuhan pribadi peserta didik dengan penyediaan ilmu yang tepat dan latihan keterampilan yang mereka perlukan, haruslah ada ketergantungan terhadap materi standar yang efektif dan terorganisasi. Untuk itu, diperlukan peran dari para guru. Mereka dituntut memiliki keterampilan teknis yang memungkinkan untuk mengorganisasikan materi standar serta mengelolanya dalam pembelajaran dan pembentukan kompetensi peserta didik.

Di tengah-tengah masyarakat yang sedang dilanda krisis multidimensional dalam segala aspek kehidupan, kemiskinan, kebodohan, kezaliman, penindasan, ketidakadilan di segala bidang, kemerosotan moral, peningkatan tindak kriminal dan berbagai bentuk penyakit sosial telah menjadi bagian tak terpisahkan dari kehidupan masyarakat. Dalam kondisi semacam ini, guru seharusnya tampil sebagai pahlawan penyelamat bangsa yang tidak saja mampu menyampaikan pesan-pesan pembelajaran kepada peserta didik, tetapi menyiapkan mereka beserta kepribadiannya untuk bisa mengarungi kehidupan yang penuh dengan berbagai tantangan. Oleh karena itu, guru harus kreatif, profesional, dan menyenangkan. Guru seperti inilah yang menjadi tumpuan harapan orang tua dan masyarakat untuk mendidik anak-anaknya dan membantu mengantarkan mereka ke jenjang kesuksesan, baik untuk hidup dalam masyarakat lokal maupun dalam dunia global. Guru demikianlah yang mampu melakukan pembelajaran secara kreatif dan menyenangkan, sehingga dapat menyiapkan peserta didik untuk memasuki era globalisasi tanpa melupakan lingkungannya. Guru ini pula yang diharapkan mampu menempa peserta didik agar dapat berpikir global dan bertindak lokal.

Guru yang diidolakan tersebut hanya akan lahir dari seorang guru yang memiliki sifat-sifat yang disyaratkan oleh Allah Swt. dalam firman-Nya.

"Hai orang yang berselimut: bangkitlah dan beri peringatan, agungkanlah Tuhanmu, bersihkanlah pakaianmu, tinggalkanlah perbuatan dosa, jangan menuntut imbalan (materi) yang berlebih-lebihan dan terhadap ketentuan Tuhanmu terimalah dengan sabar". (QS. Al-Muddatsir (74):1-7). 
Namun demikian, jabatan guru adalah dihormati oleh siapapun. Walaupun mungkin nafkah yang diperolehnya sangat minim apabila dibandingkan dengan profesi lainnya yang tidak menuntut tanggung jawab yang diberikan oleh guru. Di samping itu, dari guru inilah orang yang mengantar anak yang tadinya buta huruf menjadi melek huruf, orang yang tadinya bodoh menjadi pandai, orang yang semula dalam keadaan kegelapan menjadi terang benderang dan seterusnya.

Dengan berbekal sifat-sifat tersebut dan kesadaran terhadap amanah yang diembannya, seorang guru akan selalu konsisten melaksanakan misinya serta berjuang untuk meletakkan kembali profesi guru pada posisi terhormat dan bermartabat. Ubahlah paradigma lama dan gantilah dengan paradigma baru dalam memandang profesi guru. Buang jauh-jauh mitos dan asumsi negatif terhadap guru. Perubahan cara pandang ini harus dimulai dari para guru itu sendiri, baru kemudian disosialisasikan kepada masyarakat luas.

Dalam proses mempertahankan kualitas diri dan kualitas profesi, guru membutuhkan fasilitas untuk terus dapat melakukan satu hal yang disebut self quality improvement (perbaikan kualitas diri yang terus menerus).

Firman Allah SWT:

"Sesungguhnya Allah tidak akan merubah keadaan suatu kaum sebelum mereka (berusaha) merubah dirinya sendiri”. (QS. Al-Ra'du (13):11).

Syariat Islam dengan segala kesempurnaannya dan keluasan cakupannya telah memerintahkan supaya manusia mempelajari ilmu-ilmu yang bermanfaat mulai dari ilmu Tauhid dan Ushuluddin, Fiqih dan Hukum, bahasa Arab, sosial, budaya, ekonomi, politik, militer, kedokteran hingga ilmu-ilmu pengetahuan lainnya yang menjadi syarat tegaknya peradaban umat yang diridhai Allah SWT. (Getteng, A.R., 2014).

Profesi guru dan profesi dosen merupakan bidang pekerjaan khusus yang dilaksanakan berdasarkan prinsip sebagai berikut.

a. memiliki bakat, minat, panggilan jiwa, dan idealisme;

b. memiliki komitmen untuk meningkatkan mutu pendidikan, keimanan, ketakwaan, dan akhlak mulia;

c. memiliki kualifikasi akademik dan latar belakang pendidikan sesuai dengan bidang tugas;

d. memiliki kompetensi yang diperlukan sesuai dengan bidang tugas;

e. memiliki tanggung jawab atas pelaksanaan tugas keprofesionalan;

f. memperoleh penghasilan yang ditentukan sesuai dengan prestasi kerja;

g. memiliki kesempatan untuk mengembangkan keprofesionalan secara berkelanjutan dengan belajar sepanjang hayat;

h. memiliki jaminan perlindungan hukum dalam melaksanakan tugas keprofesionalan; dan

i. memiliki organisasi profesi yang mempunyai kewenangan mengatur hal-hal yang berkaitan dengan tugas keprofesionalan guru.

\section{Kompetensi Profesional Guru}

Sebagai suatu profesi, terdapat sejumlah kompetensi yang harus dimiliki oleh seorang guru, yaitu meliputi kompetensi pribadi, kompetensi professional, dan kompetensi sosial kemasyarakatan. 
a. Kompetensi Pribadi

Guru sering dianggap sebagai sosok yang memiliki kepribadian ideal. Oleh karena itu, pribadi guru sering dianggap sebagai model atau panutan (yang harus digugu dan ditiru). Sebagai seorang model, guru harus memiliki kompetensi yang berhubungan dengan pengembangan kepribadian (personal competencies), diantaranya:

1) Kemampuan yang berhubungan dengan pengamalan ajaran agama sesuai dengan keyakinan agama yang dianutnya.

2) Kemampuan untuk menghormati dan menghargai antarumat beragama.

3) Kemampuan untuk berperilaku sesuai dengan norma, aturan, dan sistem nilai yang berlaku di masyarakat.

4) Mengembangkan sifat-sifat terpuji sebagai seorang guru misalnya sopan santun dan tata karma.

5) Bersikap demokratis dan terbuka terhadap pembaruan dan kritik.

b. Kompetensi Profesional

Kompetensi professional adalah kompetensi atau kemampuan yang berhubungan dengan penyelesaian tugas-tugas keguruan. Kompetensi ini merupakan kompetensi yang sangat penting karena berkaitan dengan kinerja yang ditampilkan. Oleh sebab itu, tingkat keprofesionalan seorang guru dapat dilihat dari kompetensi ini. Beberapa kemampuan yang berhubungan dengan kompetensi ini, diantaranya:

1) Kemampuan untuk menguasai landasan kependidikan, misalnya paham akan tujuan pendidikan yang harus dicapai baik tujuan nasional, tujuan institusional, tujuan kurikuler, dan tujuan pembelajaran.

2) Pemahaman dalam bidang psikologi pendidikan, misalnya paham tentang tahapan perkembangan siswa, paham tentang teori-teori belajar, dan lain sebagainya.

3) Kemampuan dalam penguasaan materi pelajaran sesuai dengan bidang studi yang diajarkannya.

4) Kemampuan dalam mengaplikasikan berbagai metodologi dan strategi pembelajaran.

5) Kemampuan merancang dan memanfaatkan berbagai media dan sumber belajar.

6) Kemampuan dalam melaksanakan evaluasi pembelajaran.

7) Kemampuan dalam menyusun program pembelajaran.

8) Kemampuan dalam melaksanakan unsur-unsur penunjang, misalnya paham akan administrasi sekolah, bimbingan, dan penyuluhan.

9) Kemampuan dalam melaksanakan penelitian dan berpikir ilmiah untuk meningkatkan kinerja. (Sanjaya, W., 2005).

\section{Mempersiapkan guru untuk masa depan}

Sungguhpun sudah begitu banyak upaya dan kegiatan untuk meningkatkan mutu guru, hasil-hasil evaluasi tahap akhir siswa menunjukkan bahwa nilai mereka belum mengalami kenaikan yang berarti. 
Penataran yang dilakukan telah berhasil meningkatkan mutu guru, tetapi belum berhasil meningkatkan mutu kerja guru, sehingga mutu siswa belum meningkat. Barangkali dilihat dari semboyan Penilaian Kinerja Guru (PKG), yaitu dari guru, oleh guru, untuk guru bahwa tujuan PKG sudah tercapai. Mungkin semboyan perlu diubah, menjadi, dari guru, oleh guru, untuk guru dan siswa. Mengapa mutu guru telah berhasil ditingkatkan tetapi kemampuan kerja guru belum meningkat? Salah satu jawaban bisa kita kembalikan pada salah satu karakteristik kerja guru, yakni guru adalah pekerjaan yang tidak pernah mendapatkan umpan balik. Hal ini logis, karena tanpa umpan balik guru tidak mengetahui kualitas apa yang dikerjakan, tidak mengetahui dimana kelemahan dan kelebihan, dan akibatnya guru tidak tahu mana yang perlu ditingkatkan. Oleh karena itu, kedua model peningkatkan tersebut perlu dipertimbangkan dalam meningkatkan proses belajar mengajar.

\section{a. Hidden Curriculum}

Hidden curriculum adalah proses penanaman nilai-nilai dan sifat-sifat pada diri siswa. Proses ini dilaksanakan melalui perilaku guru selama melaksanakan proses belajar mengajar. Untuk menanamkan sikap disiplin, guru harus memberikan contoh bagaimana perilaku mengajar yang disiplin. Misalnya mulai dan mengakhiri pelajaran tepat waktu. Jika guru bertujuan menanamkan kerja keras pada diri siswa, maka guru memberikan tugas-tugas yang memadai siswa dan segera diperiksa dan diberikan kepada siswa dengan umpan balik. Kegiatan pembinaan yang diperlukan, yaitu:

1) mengkaji lebih mendalam makna hidden curriculum;

2) secara sadar merancang pelaksanaan hidden curriculum;

3) mengidentifikasi momen untuk melaksanakan hidden curriculum.

b. Self-Reflection

Self-reflection adalah suatu kegiatan untuk mengevaluasi proses belajar mengajar yang telah dilaksanakan untuk mendapatkan umpan balik dari apa yang dilakukan. Umpan balik antara lain berupa a) pemahaman siswa tentang apa yang disampaikan, b) perilaku guru yang tidak efesien dan tidak efektif, c ) perilaku guru yang efisien dan efektif, d) perilaku yang perlu diperbaiki, e) perilaku yang diinginkan oleh siswa, f) perilaku yang seharusnya dikerjakan. (Darmadi, H., 2010).

\section{SIMPULAN}

Guru adalah sosok yang berjasa dalam memajukan pendidikan. Saat manusia masih buta aksara guru selalu membantu dan membimbing peserta didik membaca dan menulis, mengajarkan peserta didik dari nol sampai menjadi sosok yang melebihi gurunya. Ketika peserta didik tidak mau menerima apa yang diajarkan, guru selalu setia membimbing dan mengarahkan supaya menjadi manusia yang berguna bagi dirinya, orang tua, masyarakat, bangsa, dan negara. Menjadi seorang guru bukanlah suatu pekerjaan yang bekerja hanya untuk mendapatkan gaji saja, tetapi memiliki profesi seorang guru berarti ada tugas mulia yang sedang diemban. Menjadi guru adalah sebuah pengabdian, mengabdi untuk kecerdasan bangsa. 


\section{DAFTAR PUSTAKA}

Alma, B. (2010). Guru Profesional (Menguasai Metode dan Terampil Mengajar). Bandung. Bafadal, I. (2008). Peningkatan Profesionalisme Guru Sekolah Dasar. Jakarta: Bumi Aksara.

Darmadi, H. (2010). Kemampuan Dasar Mengajar (Landasan dan Konsep Implementasi). Bandung.

Drajat, M. (2014). Etika Profesi Guru. Bandung.

Getteng, A. R. (2014). Menuju Guru Profesional dan Ber-Etika. Yogyakarta: Grha Guru.

Pemerintah Indonesia. (2003). Undang-Undang No. 20 Tahun 2003 tentang Sistem Pendidikan Nasional.

Sanjaya, W. (2005). Pembelajaran dalam Implementasi Kurikulum Berbasis Kompetensi. Jakarta. 